\title{
PSYCHOLOGICAL CHANGES IN THE FAMILY SYSTEM DURING QUARANTINE
}

У статті викладено проблему психологічних змін у сімейних системах, що перебувають в умовах карантинних обмежень, особливості сімейних взаємин, зокрема зміни в сімейній системі в умовах життєдіяльності сім'ї під час пандемії та карантину. Зроблено спробу узагальнити ті знання, які здобуті в процесі вивчення сім'ї як системи в психолого-педагогічних дослідженнях з урахуванням нових умов.

Аналізуючи ситуацію, що склалася, і ті психологічні зміни, які можна спостерігати всередині сімейних систем, можемо стверджувати, що особливості перебування сім'ї у карантинних умовах відповідають особливостям співіснування груп в умовах ізоляції. Проте ізоляція людини розглядається більше у військовій, кризовій, екстремальній та пенітенціарній психологі та майже не розглядається у сімейній, тому здійснено аналіз змін у сімейній системі, які відбуваються під час карантинних обмежень та ізоляції сім'ї на невизначений тривалий термін. Розкрито психологічну сторону перебування всіх членів родини довгий час разом на обмеженому просторі, що викликає перенапруження увагою, перетином інтересів і потреб, порушенням особистого простору.

Визначено, що для позначення виниклих умов прийнятним $є$ термін «вимушена близькість», який за характеристиками відповідає тенденціям перебування певних груп в умовах ізоляції тривалий час. Наслідком цього є постійне перенапруження увагою, перетином інтересів і потреб, порушенням особистого простору. Саме це підтверджують як дослідження автора, так і офіційна статистика щодо кількості розлучень з початку карантину (збільшення на 1,8\%) та зменшення реєстраціі шлюбів (на 36,6\%).

Вироблення нових, оптимальних саме для cuтуації пандемії, ізоляції та обмежень сімейних правил, які можуть стосуватися будь-яких аспектів життєдіяльності сім'ї, як режиму дня, правил взаємодії, так і можливості відкритого вираження почуттів, ставлень, потреб, може стати тією знахідкою у кризові часи, що допоможе прожити чей час оптимально й навіть відчути радість від спілкування членів родини один з одним.
Ключові слова: сім'я, сімейна взаємодія, пандемія, карантинні обмеження, ізоляція, вимушена близькість.

The article presents the problem of psychological changes in family systems under quarantine restrictions, features of family relationships, in particular changes in the family system in the conditions of family life during pandemics and quarantine. An attempt is made to generalize the knowledge gained in the study of the family as a system in psychological and pedagogical research, taking into account the new conditions. Analyzing the current situation and the psychological changes that can be observed within the family systems, we can say that the peculiarities of the family in quarantine conditions correspond to the peculiarities of the coexistence of groups in isolation. However, human isolation is considered more in military, crisis, extreme and penitentiary psychology and is hardly considered in family psychology. Therefore, an analysis of changes in the family system that occur during quarantine restrictions and isolation of the family for an indefinite period. The psychological side of all family members being together for a long time and in a limited space is revealed, which causes an overstrain of attention, intersection of interests and needs, violation of personal space. It is determined that the term "forced intimacy" is acceptable to denote the conditions that have arisen, which in terms of characteristics corresponds to the tendencies of finding certain groups in isolation conditions for a long time. The consequences of which are constant stress, intersection of interests and needs, violation of personal space. This is confirmed by both the author's research and official statistics on the number of divorces since the beginning of quarantine (an increase of 1.8\%) and a decrease in marriage registration (of $36.6 \%$ ).

The development of new, optimal for the situation of pandemic, isolation and restrictions, family rules that can relate to any aspect of family life - as a daily routine, rules of interaction, and the ability to openly express feelings, attitudes, needs, may be the discovery in times of crisis, which will help to live this time optimally, and even feel the joy of family communication with each other.

Key words: family, family interaction, pandemic, quarantine restrictions, isolation, forced intimacy.
Харківський національний університет внутрішніх справ
Постановка проблеми. Життєдіяльність сімейної системи підкоряється двом законам, а саме закону гомеостазу і закону розвитку. Закон гомеостазу наголошує на тому, що будь-яка система прагне до стабільності та спокою. Для родини це означає, що вона постійно прагне зберегти status quo. Закон розвитку говорить про те, що кожна соціальна чи біологічна система прагне досягнути найбільшого сумарного потенціалу, проходячи всі етапи життєвого циклу. Будь-яке порушення стабільності завжди негативно позначається на всіх членах сім'ї, незважаючи на те, що події можуть бути негативними (хвороба одного з членів родини, розлучення тощо), або радісними і довгоочікуваними (наприклад, народження дитини, розпад нещасливого шлюбу). Все це вимагає переналаштування сімейних стосунків відповідно до нових умов.

Як зазначено, будь-яка сімейна система прагне пройти повний життєвий цикл найбільш ефективно, проходить у своєму розвитку певні стадії, пов'язані з неминучими об'єктивними обставинами. Серед таких 
обставин є фізичний та соціальний час. Так, постійно змінюється вік членів сім'ї, відбувається вихід із сім'ї дітей, змінюється форма взаємодії сім'ї з оточенням і соціумом (навчання, професійна діяльність і її зміни тощо), тому змінюється сімейна ситуація загалом. Вкрай важливо те, що сучасна сім'я не є замкненою ізольованою системою, вона формується багато в чому під впливом соціуму, сама впливає на нього, вимагаючи враховувати свої потреби, тобто сім'я як самостійна система і кожен з її членів окремо залучені у соціальні стосунки й залежать від тих умов, які висуває до них спільнота (держава). Це визначає стиль соціального існування, стабільність і перспективи самої сім'ї.

З часу останніх загальносвітових потрясінь (воєн, пандемій, катастроф) в Україні та у світі утворилися умовно стабільні й достатньо визначені умови і правила співіснування людей і груп, зокрема сімейних. Несподіваним для всіх людей нашої країни і світу загалом стало виникнення спалаху інфекції Covid-19 у грудні 2019 р. у м. Ухань (КНР) та визнана ВООЗ загальна пандемія від 11 березня 2020 р. Особливістю захворювання стало швидке поширення хвороби повітряно-крапельним шляхом, через що владами було прийнято рішення обмежити спілкування людей, тобто ввести карантин. Спочатку на місяць, згодом його було продовжено на два місяці, загалом ситуація з карантином триває вже більше року, якщо брати світ загалом, і остаточного завершення прогнозувати не зважиться ніхто. З економічної точки зору найбільшим ризиком $€$ суттєве зниження міждержавної взаємодії, яку дещо рятують сучасні технології, що дають змогу обмежити безпосередній контакт, не зупиняючи повністю економічну діяльність. 3 психологічної точки зору найбільші ризики несуть нові правила взаємодії, які перш за все відбилися на родинах, не тільки обмеживши взаємодію між деякими членами родини, але й, що незвично для сучасного світу, сконцентрувавши та ізолювавши членів сім'ї у замкненому просторі на довгий і невизначений проміжок часу. Родини зіткнулися з новими умовами життя. 3 одного боку, батьки змогли проводити більше часу з дітьми, бо всі так цього хотіли, а з іншого боку, нова форма організації буття сім'ї стала випробуванням для багатьох, люди стали сидіти днями у своїх домівках, поєднуючи сімейне життя й роботу, і чекати на зміни ситуації, тому проблема психологічних змін у сімейних системах, що перебувають в умовах карантинних обмежень, заслуговує на особливу увагу і наукову дискусію цієї актуальної тематики.

Аналіз останніх досліджень і публікацій. Психологія сім'ї має у своєму розпорядженні великий досвід досліджень різних аспектів і сфер функціонування сім'ї, таких як характер подружніх стосунків, особливості характеру батьків, етапи виховання дитини і ставлення до неї батьків (Ю.Є. Альошина, М. Боуен, Д. Віннікот, Г.Я. Варга, К. Вітакер, В.М. Дружинін, У. Кемплер, Г. Навайтіс, А.С. Співаковська, Е.Г. Ейдеміллер, В. Юстицкіс) [10]. Щодо проблем стабільності шлюбу та сім'ї, умов створення психологічно здорової сім'ї, то це відображено в роботах С.В. Ковальова, В.А. Сисенко [8]. Особливості впливу сімейних взаємостосунків на становлення особистості дитини вивчали O.I. Бондарчук, Г.Я. Варга, B.I. Гарбузов, Т.В. Говорун, О.І. Захаров, Е.Г. Ейдеміллер [3]. Сім'я як система вивчається в педагогіці, психології та сімейній психотерапії. Вивчення систем бере свій початок у системології, кібернетиці, загальній теорії систем, системному аналізі.

Зауважимо, що, незважаючи на активний розвиток дослідження у сфері психології сім'ї, деякі особливості сімейних взаємин, зокрема зміни в сімейній системі, пристосування до нових умов життя сім'ї під час пандемій і карантину, досліджені мало. Нами зроблена спроба узагальнити ті знання, які здобуті в процесі вивчення сім'ї як системи в психолого-педагогічних дослідженнях з урахуванням нових умов.

Вже певний час у суспільстві активно розвиваються інформаційні, електронні технології, які дають змогу виконувати діяльність (навчальну, професійну) віддалено, дистанційно. Однак ці технології не набували масовості, а були прив'язані до певних умов (наприклад, автоматизація виробництва, IT-компанії) або потреб, наприклад, пов'язаних із розвитком навчання дітей з особливими потребами, з особливостями розвитку, дітей з інвалідністю. Нині у зв'язку з пандемією і карантином дистанційні технології починають набирати обертів та стають більш затребуваним. Що важливо, ці технології - це одна із зовнішніх сторін ситуації, яка передусім характеризується ізольованістю людей і перебуванням їх довгий час разом у достатньо замкненому просторі. Найбільше це відбилося саме на сімейних системах.

Ціла низка науковців здійснювала дослідження впливу супутніх негативних явищ на психіку людини в умовах різних видів ізоляції, зокрема П.В. Будзен, Л.Є. Паніна, В.П. Соколова (вплив природних чинників на психічний стан членів полярних експедицій) [6], С.С. Корсаков (наслідки довготривалої госпіталізації з постільним режимом) [2], О.М. Кузнєцов, В.І. Лєбєдєв, М.М. Ханаіашвілі, П.Б. Ганнушкін, Е. Кречмер (вплив умов соціальної ізоляції на особистість та міжособистісні відносини) [3], І.К. Кеєлєйников, І.Ф. Рябінін (особливості спілкування в умовах групової ізоляції) 
[4, с. 34, 83]. Ізоляція людини розглядається більше у військовій, кризовій, екстремальній та пенітенціарній психології та майже не розглядається у сімейній. Однак, аналізуючи ситуацію, що склалася, і ті психологічні зміни, які можна спостерігати всередині сімейних систем, можемо стверджувати, що особливості перебування сім'ї у карантинних умовах відповідають саме цим характеристикам.

Постановка задання. Метою статті $€$ здійснення аналізу та виявлення змін у сімейній системі, які відбуваються під час карантинних обмежень та ізоляції сім'ї на невизначений тривалий термін.

Виклад основного матеріалу дослідження. Сімейна система як простір тісної взаємодії, виховання й навчання $є$ великим ресурсом, у якому людина може черпати все різноманіття людського досвіду. За сприятливих умов саме сім'я закладає ресурс розвитку й соціалізації особистості, за несприятливих обставин сімейна система може деформувати ресурси особистості, її світосприйняття та блокувати її успішну самореалізацію в майбутньому [1].

Сім'я як система вперше виступила об'єктом дослідження у 1975 р. в працях американського психотерапевта Мюррея Боуена. Відповідно до концепції М. Боуена, всі форми життя $€$ системами. Він запропонував нові підходи до вивчення людської поведінки через призму сімейних стосунків. Виділяючи сімейну систему з низки живих систем, М. Боуен визначив відмінності сімейної системи. Він стверджує, що члени сім'ї не можуть діяти незалежно один від одного, тому що така поведінка призводить до внутрішньо-родинної дисфункціональності. В теорії сімейних систем М. Боуен, як і Д.T. Вілсон (D.T. Wilson, 1995), припустив, що функціонування і принципи організації такої системи є спільними для всіх видів живих істот, які мають складну суспільну організацію. Це означає, що велика частина людської поведінки $€$ автоматичною, зумовленою впливом системи і не підвладна повною мірою контролю з боку індивідуума [7]

Більшість дослідників вивчає сімейні стосунки у звичайних динамічних умовах, які змінювалися поступово, з часом, що дає змогу прогнозувати, моделювати сімейну систему. Сучасність вводить у сімейні системи нові соціальні чинники, а саме жінки у XX - XXI столітті стали більше часу приділяти власному розвитку та робити акцент на особистій кар'єрі, в сім'ях поступово стала зменшуватись кількість дітей, умови самого життя вдома стали набагато кращими порівняно з тими, які були, наприклад, 100 років тому, стосунки у сім'ї стали більш вільними, позбавленими багатьох стереотипів, норм, сім'я втратила свою закритість, недоторканність і стала більш соці- альною. Суспільне життя людей стало розвиненим, люди переїжджають з континенту на континент, спілкуються на роботі, відвідують різноманітні заходи, піддаються певним соціальним тенденціям у спрямуванні виховного впливу тощо. Однак знову наголосимо на тому, що всі зазначені зміни відбувалися в сімейній системі поступово, упродовж певного часу, що дає змогу сімейній системі ефективно інтегрувати зміни у власну взаємодію.

Щодо умов пандемії і карантину, які виникли у 2019 р., а у 2020 р. карантин ввели фактично раптово, то ніхто із сучасних людей і сімей до цього часу не стикався з такою проблемою. В чому ж полягає саме проблема карантину і цілодобового перебування сімей вдома разом? Було опитано 120 людей віком від 20 до 70 років, і 82\% з них сказали, що одними з основних ускладнень $є$ обмеження безпосереднього спілкування разом з постійною взаємодією з рідними в обмеженому просторі, що у сучасному світі вже не є нормою, зміна графіку й особливостей трудової діяльності і навчання дітей шкільним предметам (переважання дистанційних форм). Так, певний час тому почало інтенсивно розвиватися дистанційне (домашнє) навчання, що пов'язано з розробленням форм навчання дітей з особливими потребами, дітей з особливостями розвитку, дітей з інвалідністю, за загальними освітніми програмами. Нині у зв'язку з карантином дистанційне (домашнє) навчання починає набирати обертів та стає все більш затребуваним. Навіть ті, хто працював вдома до карантину, не навчав дітей, а лише допомагав виконувати домашнє завдання, під час самого карантину довелося бути присутніми під час уроків та пояснювати матеріал, враховувати постійне перебування дітей вдома з усіма наслідками такої ситуації (необхідність постійної взаємодії і контроль, перетин потреб тощо).

Також 94\% зазначили, що невизначеність часу дуже болісно відображається на внутрішньому стані, люди чекають на закінчення, на повернення до життя, яке їм більш звичне.

Психологічна сторона незвичного для сучасного соціального ритму життя більшості людей, перебування всіх членів родини довгий час разом на обмеженому просторі - це постійне перенапруження увагою, перетином інтересів і потреб, порушенням особистого простору, прискіпливістю, зауваженнями один до одного, загостренням претензій. Це найбільше відчули на собі сімейні системи, адже ізоляція відбулася саме на їх рівні. Люди не відволікаються на інших, коло спілкування обмежується тільки членами сім'ї, тому вони починають дошкуляти один одному. У психології є термін «психологічний вампіризм», що $€$ грубим, неконтрольованим бажанням одержати задоволення за найменшої витрати сил, 
постійним прагненням до легкого способу підняти собі настрій за рахунок інших. Під час карантинних обмежень, відсутності достатньої кількості спілкування цілком можна ввести новий термін, схожий на психологічний вампіризм, а саме «карантинний вампіризм», який визначає спробу задоволення нереалізованих соціальних потреб та зняття емоційного напруження через тих, хто перебуває поряд, тобто членів родини, а підсилює ситуацію його обопільність.

Проте $є$ й ті, кого влаштовують карантинні обмеження. Якщо розглянути анкети детальніше, то це люди, які до цього часу працювали вдома (програмісти, мережевий бізнес, бухгалтери тощо), тобто люди, які звикли до життя і роботи вдома онлайн. Також спостереження показують, що людям із тривожними та обсесивно-компульсивними розладами, депресією, соціофобією, високим рівнем інтровертованості стало краще виконувати певні соціальні функції. За масками можна «сховатися», ізоляція і робота вдома дають змогу обмежити кількість соціальних контактів без викликання претензій на свою адресу.

Отже, постійне спільне перебування 24 години на добу і 7 днів на тиждень (24/7) може привести до того, що одні сім'ї будуть зміцнюватися, а інші зрозуміють, що їм не судилося бути разом. Проблемою карантину та цілодобового перебування подружніх пар і сімей разом стає ще й те, що люди не відпочивають один від одного, не звикли до такого стилю та інтенсивності спільного існування. У психології навіть $€$ термін «вимушена близькість», який за характеристиками відповідає тенденціям перебування певних груп в умовах ізоляції тривалий час. Вимушена близькість характеризується постійним спілкуванням окремої групи людей у замкненому просторі, обмеженим колом спілкування, одноманітністю обстановки, соціальною депривацією, загостренням чи зіткненням матеріальних і духовних інтересів, підвищеною напруженістю функціональних систем організму, а щодо сімейних систем - змішуванням професійної діяльності, побуту й відпочинку. За характером впливу ізоляція буває вимушеною або примусовою (позбавлення волі, карантин) і добровільною (експедиція, аскетизм, чернецтво). Однак якою б не була ізоляція, вона разом із почуттям емпатії і турботи один про одного викликає загострення інтенсивності психосоціальних стресорів, підвищує ризик рецидивів попередніх станів здоров'я, зокрема психічних захворювань, викликає постійний стрес, недарма ізоляція може бути формою покарання. Навіть у людей, які мають стійку стабільну психіку, можуть з'являтися тривожні стани, напруження, гострий стресовий розлад. Проте значна частина людей з часом адаптується до змін та самостійно долає наслідки тривалого стресу.

Звернемося до офіційної статистики України щодо кількості розлучень з березня по грудень 2019 р. і впродовж аналогічного періоду 2020 р. За даними Міністерства юстиції України, розлучень у 2020 р. на 1,8\% більше. Звичайно ж, різниця не є дуже великою, але на теренах країни це все ж таки чималенька кількість, і карантин ще триває, часу пройшло порівняно небагато. Більш детальний аналіз та порівнянність можна буде провести через декілька років. До того ж є ще одна цікава статистика стосовно реєстрації шлюбів у 2020 р., яка порівняно з 2019 р. знизилась аж на 36,6\%. Звичайно, у сучасних сім'ях існує тенденція до спільного проживання без реєстрації шлюбу, але за рік це надвеликий стрибок, тому можна передбачити, що карантинні обмеження на реєстрацію шлюбу, святкування самого весілля та загальний психологічний і матеріальний стан подружніх пар вплинули суттєво.

Нині питання щодо повноцінної допомоги сім'ям, пов'язаної з навчанням, вихованням дітей, корекцією взаємодії та емоційних переживань, стають вкрай актуальними через карантинні обмеження й постійну неперервну взаємодію усіх членів сім'ї. Робота має бути побудована на принципах, які закладені у напрямах психології (військова, кризова, екстремальна, пенітенціарна), які розглядають принципи ефективності функціонування груп в умовах вимушеної ізоляції, близькості, обмежень, як соціальних, так і у просторі, вплив невизначеності на психіку особистості і групи. Ситуація, що склалася у зв'язку з пандемією та карантинними обмеженнями, ставить сім'ї саме в такі, не звичні для сімейної психології умови.

До того ж стають нагальними освіта дорослих, розвиток батьків як учителів своїх дітей, особистісний та професійний їх розвиток у нових умовах. Важким є поєднання навчання власних дітей та особистої професійної діяльності, навіть якщо є можливість працювати дистанційно, адже не завжди можна зосередитися на роботі, коли декілька людей поєднують свою відмінну діяльність на обмеженому просторі, коли доводиться постійно перелаштовувати графік роботи, коли тебе весь час відволікають, нехай навіть близькі люди. Якщо ж не можна працювати дистанційно, то ситуація стає вкрай важкою, бо, залишаючи дітей вдома, батьки не можуть точно знати, що вони саме навчаються, що відбувається вдома, і це підвищує емоційне напруження до максимуму. Отже, реалізуючи сімейні, зокрема батьківські, ролі, доросла людина постійно розвивається, змінюється і поповнює запас знань та вмінь. У цьому динамічному процесі немає фінальної точки, діти є тим барометром, який 
визначає ступінь компетентності та ефективності батька як учителя, інформатора, педагога й наставника, адже саме цей аспект поступово делегувався у соціум, нині склалися умови (карантинні обмеження), за яких ці ролі «повернулися» у сім'ю.

У зв'язку з раптовими, несподіваними обставинами, які склалися у 2019-2020 рр., регуляторами сімейної системи мають стати нові сімейні норми й правила, сімейні цінності та ритуали, які кожній сім'ї необхідно переорієнтувати та визначити якщо не на подальше майбутнє сім'ї, то щонайменше на період карантинних обмежень. А.Б. Холмогорова ці характеристики називає змістовними основами життя сім'ї (2002 р.). Інші автори називають їх сімейними стабілізаторами (Е. Ейдеміллер, І.В. Добряков, І.М. Нікольська, 2003 р.). У цьому аспекті варто взяти до уваги те, що запропоновані визначення недостатньо повно розкривають вплив цих характеристики на сімейне функціонування. Традиційно їм приписується функція підтримки рівноваги в сімейній системі. Однак одні й ті ж чинники в різні періоди життя сім'ї та під впливом особливих умов, таких як карантин, можуть як стабілізувати, так і дестабілізувати сімейну систему загалом.

Важливим компонентом життя родин стає фінансова криза. Глен Сандстрем, який вивчає демографічну історію в Університеті Умео у Швеції, зазначає, що так завжди відбувається під час економічних спадів, принаймні з часів Другої світової війни. Фінансова стабільність одна з найважливіших опор у сімейній системі. Під час пандемії багато людей зіткнулися зі зниженням доходів, що підвищило напругу у стосунках. Постійні думки й переживання на фінансові теми знижують якість стосунків. Втрата доходів і роботи може стає серйозним ударом по самооцінці, насамперед для чоловіків, для яких здатність забезпечити родину все ще залишається важливим чинником самоповаги. В результаті це призводить до тривоги, гніву та розчарування, а також підвищує ймовірність сімейних конфліктів. Варто зазначити, що 98\% опитаних нами піддаються загальним негативним тенденціям у суспільстві та підхоплюють панічні й негативні настрої загалу. Навіть ті, яких карантин не зачепив, вважають, що їх життя стало гіршим. Якщо брати суспільство загалом і сім'ї зокрема, то ця негативна тенденція суттєво вплине на зростаюче покоління, яке живе під впливом негативізму.

Вирішальним, нагальним, важливим, суттєвим завданням із формування сімейних правил під час ізоляції і карантинних обмежень $€$ визначення способу взаємодії членів сім'ї. Відсутність правил і норм найчастіше призводить до хаосу в сімейній системі, а також є серйозною небезпекою для психічного здоров'я членів сім'ї. Так, багато дітей з девіантною, неадекватною поведінкою виросли в сім'ях, що характеризуються хаотичністю. Нечіткість правил і норм, їх постійна мінливість сприяють зростанню тривоги у членів сім'ї і можуть призводити до стресів, конфліктів, а також гальмувати розвиток як усієї сімейної системи, так і окремих її членів. Правила ж дають змогу членам сім'ї орієнтуватися в наявній реальності й надають стійкості сім'ї загалом.

Нові умови життя вимагають створення нових правил у сімейній системі, оперативної вимушеної їх перебудови. Необхідно навчитися жити, а не переживати нові умови, прийняти зміни, формувати нові уміння й способи взаємодії членів сім'ї. Життя в період пандемії і карантинних обмежень як її наслідку, нові форми існування, які не були типовими до цього часу, мають згуртувати родини, а не руйнувати їх. До речі, пандемія та криза для когось можуть стати можливістю переосмислити своє життя та вибрати новий шлях.

Висновки 3 проведеного дослідження. Отже, вироблення нових, оптимальних саме для ситуації пандемії, ізоляції та обмежень сімейних правил, які можуть стосуватися будьяких аспектів життєдіяльності сім'ї, як режиму дня, правил взаємодії, так і можливості відкритого вираження почуттів, ставлень, потреб, може стати тією знахідкою у кризові часи, що допоможе прожити цей час оптимально й навіть відчути радість від спілкування членів родини один з одним.

Можна впевнено стверджувати, що простір сімейної взаємодії стає все більш цікавим об'єктом дослідження для психології сім'ї та психології особистості, починають формуватися нові напрями досліджень, зокрема емоційні зв'язки в сімейній замкненій системі, сучасні культурологічні традиції, методи й форми навчання в сім'ї, сімейна освіта, вплив дистанційного навчання, соціальних потрясінь та перетворень на сімейні системи.

Попередити негативні психологічні процеси в сім'ях і в суспільстві можна завдяки впровадженню програми підтримки сімей, спрямованої на підготовку до нових умов життя в період карантину та інших надзвичайних ситуацій, з урахуванням специфіки ізольованості окремих соціальних груп (і сімей особливо) та перебудови життя суспільства загалом. Засобам масової комунікації необхідно налаштовувати загал на позитивні тенденції, стимулювати пошуки нових можливостей життя, поєднання сімейного життя та роботи, вчити життю в умовах кризи, а не переживання й очікування її, тобто виконувати роль «дистанційного психотерапевта», який допомагає, навчає, пристосовує до життя в умовах карантинних обмежень. Сім'ї, які не можуть подолати труднощі, пов'язані з новими умовами, мають зверта- 
тися до сімейних психологів та психотерапевтів, а не намагатися самостійно впоратися з цими проблемами чи очікувати повернення до сталого життя.

Перспективи подальшого дослідження цього аспекту полягають у встановленні соціально-психологічної залежності між особливостями внутрішньосімейних взаємин та зародженням конфліктів «подружжя діти - батьки» підчасжиттятанавчання вперіод вимушеної ізоляції сім'ї, а також розробленні методів психологічної корекції поліпшення сімейних взаємин.

\section{ЛІТЕРАТУРА:}

1. Голод С.И. Семья и брак: историко-социологический анализ. Санкт-Петербург : Петрополис, 1998. 272 c.

2. Корсаков С.С. Вопросы клинической психиатрии. Москва : Стереотип, 2010. 264 с.

3. Кузнецов О.Н., Лебедев В.И. Достоевский о тайнах психического здоровья. Москва, 1994. 387 с.
4. Келейников И.К. Конформизм и распределение ролей в условиях длительной изоляции. Клинико-психологические исследования личности. Ленинград, 1971. С. 34.

5. Якубова Ю.М., Антонова-Турченко Ю.Г., Святненко Г.В., Московка М.М. Проблемні сім'ї: діти і батьки. Київ : Український інститут соціальних досліджень, 1998. 137 с.

6. Панин Л.Е., Соколов В.П. Психосоматические взаимоотношения при хроническом эмоциональном напряжении. Новосибирск : Наука, 1981. 176 с.

7. Теория семейных систем Мюррея Боуэна: Основные понятия, методы и клиническая практика. Москва : Когнито-Центр, 2005. 496 с.

8. Сысенко В.А. Устойчивость брака: проблемы, фракторы и условия. Москва, 2001. 210 с.

9. Шишкина О.В. К вопросу о современных супружеских отношениях. Психология и педагогика - новая интеграция : материалы 24-й научной конференции. Санкт-Петербург : ГАФК им. Лесгафрата, 1998.

10. Юстицкис В. Психология и психотерапия семьи. Санкт-Петербург : Питер, 2008. 356 с. 